\title{
Community acquired pneumonia incidence among children less than 5 years of age in Concordia, Argentina: vaccination impact
}

\author{
Raúl O. Ruvinsky, ${ }^{1}$ Analía Rearte, ${ }^{1}$ Judit Kupervaser, ${ }^{2}$ Fernando Gentile, ${ }^{3}$ \\ Adriana Haidar, ${ }^{2}$ Maria E. Cafure, ${ }^{4}$ Maria ElisaTito, ${ }^{2}$ Federico Avaro, ${ }^{5}$ \\ Cristina Cortiana, ${ }^{6}$ Hugo Cozzani, ${ }^{3}$ Omar Véliz, ${ }^{7}$ Sofia Fossati, ${ }^{7}$ \\ Mabel Regueira, ${ }^{7}$ and Carla Vizzotti ${ }^{1}$
}

Suggested citation Ruvinsky RO, Rearte A, Kupervaser J, Gentile F, Haidar A, Cafure ME, et al. Community-acquired pneumonia incidence among children less than 5 years of age in Concordia, Argentina: vaccination impact. Rev Panam Salud Pública. 2018;42:e167. https://doi.org/10.26633/RPSP.2018.167

ABSTRACT Objective. To measure the effectiveness of pneumococcal conjugated vaccine (PCV13) against Community Acquired Pneumonia (CAP) and invasive pneumococcal disease, 2 years after the vaccine $(2+1)$ was included into the National Immunization Program of Argentina, and to describe variables associated with bacterial pneumonia and hospitalization.

Methods. This was a prospective, population-based surveillance study of CAP incidence (ambulatory and hospitalized) among children less than 5 years of age in the Department of Concordia (Entre Rios, Argentina) from April 2014 - March 2016. The diagnosis of probable bacterial pneumonia (PBP) was determined following the standardized WHO protocol. Incidence during the post-vaccine introduction period was compared with the results from a previous study that used similar methodology for the pre-PCV13 introduction period from $2002-2005$.

Results. During the study period, 330 patients had a clinical diagnosis of CAP, of which 92 were PBP (6 with pleural effusion). S. pneumoniae was not isolated from any sample. No factors associated with PBP were found in multivariable analysis. The decrease in PBP and pleural effusion was significant in relation to the previous study: $63 \%(P<0.0001)$ and $80.9 \%(P<0.003)$, respectively. PCV13 uptake was $97.3 \%$ for the 1 st dose and $84.8 \%$ for the booster dose.

Conclusions. PCV13 was effective to reduce incidence of consolidated pneumonia and pleural effusion, among children less than 5 years of age in Concordia, Argentina. Vaccination is a very effective public health strategy for reducing vaccine preventable diseases, with impact on burden of disease and hospitalization.

Keywords Pneumonia, pneumococcal; Streptococcus pneumoniae; pneumococcal vaccines; immunization programs, Argentina.

\footnotetext{
Dirección de Control de Enfermedades Inmunoprevenibles, Ministerio de Salud de la Nación, Buenos Aires, Argentina.

2 Hospital Delicia Concepción Masvernat, Concordia, Entre Ríos, Argentina.
}

Hospital de Niños Ricardo Gutiérrez, Buenos
Aires, Argentina.
Centro Provincial de Salud Constitución,
Concordia, Entre Ríos, Argentina.
5 Hospital Felipe Heras, Concordia, Entre Ríos,
Argentina.
Hospital Ramón Carrillo, Concordia, Entre Ríos, Argentina
Bacteriología Clínica, Instituto Nacional de Enfer- medades Infecciosas, Administración Nacional de Laboratorios e Institutos de Salud "Dr. Carlos Malbrán," Buenos Aires, Argentina.


Community-Acquired Pneumonia (CAP) is a highly prevalent cause of morbidity and mortality worldwide, with its greatest impact being among lowincome population groups $(1,2)$. In 2000, 1.8 million deaths were reported in children less than 5 years of age $(30 \% \mathrm{CAP})$, most in developing countries (3). A more recent publication reported that CAP caused significant morbidity and mortality, greater than 2 million deaths annually worldwide in children less than 5 years of age (4). In 2010, Nahir and colleagues published a systematic review estimating 11.9 million (95\% Confidence Interval [95\%CI]: 10.3-13.9 million) episodes of severe and 3.0 million (95\%CI: 2.1-4.2 million) episodes of very severe, acute, lower respiratory infections causing hospital admissions in young children worldwide (5).

In Latin America and the Caribbean (LAC), high mortality per CAP in children was estimated, with Streptococcus pneumoniae representing the vast majority of the bacterial etiology of those cases $(6,7)$. Due to limited microbiological isolation, the World Health Organization (WHO) proposed a protocol (8) that considers a consolidation in the chest X-ray as probable bacterial pneumonia (PBP). Ferrero and colleagues (9) conducted a study on CAP in Argentina, Brazil, and the Dominican Republic that validated WHO protocol. In 283 cases with $S$. pneumoniae isolation, $75.2 \%$ were chest $\mathrm{X}$-ray consolidations (Odds Ratio [OR] = 1.7; 95\%CI: 1.2 - 2.6).

In LAC countries, the Pan American Health Organization (PAHO) sponsored several population-based surveillance studies to determine CAP incidence among children less than 5 years of age. CAP represents a very important public health issue in the region, with high incidence rates of 1928 / 100000 in Chile (10); 3428 in Goiana, Brazil (11); and, in Uruguay, 1692 - 1838 among those less than 12 months of age and $1757-2017$ among those $12-23$ months of age (12).

In Argentina, similar studies have been carried out. In Pilar City, Buenos Aires, the incidence rate was $750 / 100000$ among those less than 5 years of age, and 1922 among those less than 1 year (13). Concordia and Paraná Departments in Entre Rios province showed similar rates of 1100 among those less than 5 years, and 2000 for those less than 2 years $(13,14)$. Finally, a study of Córdoba City also reported high incidence rates: around 2422 among those less than 2 years of age (15).
Pneumococcal conjugated vaccines (PCV) have demonstrated high efficacy in preventing CAP when used on various schedules (16 - 18). In January 2012, PCV13 was incorporated into Argentina's National Immunization Program (NIP) with a $2+1$ schedule: two vaccinations within $2-4$ months of age and a booster at 12 months (19).

The objectives of the present study were to measure PCV13 effectiveness, 2 years after universal vaccination, by determining incidence of PBP and invasive pneumococcal infections among children less than 5 years of age, and comparing it to a previous study in 2002 - 2005 (14). The clinical and epidemiologic traits of children with CAP diagnosis were characterized and correlated with vaccination status and variables associated with PBP requiring hospitalization.

\section{MATERIALS AND METHODS}

This was an observational, prospective, population-based surveillance study of incidence of PBP and pneumococcal infections incidence in the Department of Concordia, Entre Ríos Province, Argentina, during the period 1 April $2014-30$ March 2016.

\section{Study setting}

Concordia has a total population of 170000 inhabitants, with 15493 less than 5 years of age and 6500 less than 2 years. The Delicia Concepción Masvernat General Hospital (250 beds, 50 pediatric, and $4 \mathrm{ICU}$ ) is the reference institution for hospitalization of all Concordia residents. More than 95\% of hospitalized patients are served by this hospital. Ambulatory care is covered by the Ramón Carrillo and Las Heras hospitals (both with radiology equipment) and 17 Health Care Centers (1 with radiology service). Data were collected from all centers that had radiology equipment.

\section{Study population}

All children under 5 years of age with clinical diagnosis of CAP, who underwent a chest $X$-ray, and were admitted to the reference hospital or ambulatory care, were included in the study. Nosocomial pneumonia cases were excluded. A new CAP event was considered after 1-month of discharge.

\section{Data collection}

An ad hoc survey form was designed and completed in each of the four centers with radiology equipment; data were collected by interview and medical history reports. Outpatients were referred for control and data collection to an office created for the study. All included children had a chest X-ray, scanned by digital camera. Pediatricians and a reference radiologist informed independently on chest X-ray results. A second reference radiologist arbitrated when discordances occurred.

Data from a previous study (14) in Concordia (2002 - 2005) was used as a baseline to evaluate PBP incidence during the pre-PCV13 introduction to NIP. The original database was used to describe incidence during that period. Data from the current study was evaluated to estimate the incidence of PBP after PCV13 was added to the NIP.

\section{Study variables}

Community-acquired pneumonia. CAP was categorized into:

- Probable bacterium pneumonia, including:

- Consolidated pneumonia: according to WHO criteria for interpretation of chest X-rays (8);

- Pneumonia with pleural effusion;

- Pneumococcal confirmed pneumonia: isolation of $S$. pneumoniae in blood or pleural fluid, regardless of the type of infiltrate.

- Non-bacterial pneumonia: chest $X$-rays with interstitial infiltrate or without any pathological finding.

PBP incidence was calculated for all children less than 5 years of age, by age group, according to the 2010 National census data (20).

\section{Other variables.}

- Socioeconomic level, determined according to modified Graffar scale (21)

- Nutritional status

- Attending nursery school or prekindergarten program

- Number of persons sleeping per room

- Hospitalizations during the previous 3 months

- Underlying disease

- Severity: those who required intensive care unit hospitalization 
- Vaccination status: considering complete schedule according to the age and incomplete if any dose was missing

- Vaccination coverage: calculated for each dose. The proportion of vaccinated children compared to the total number of children who should have been vaccinated, according to their age

\section{Laboratory diagnosis}

Bacterium etiological diagnosis. Blood cultures and pleural fluid cultures (if the patient required thoracocentesis) were performed in all hospitalized patients. Samples with the usual methodology for bacterial identification were analyzed at the Masvernat Hospital laboratory.

Isolation of S. pneumoniae. The isolates would be submitted to the Infectious Diseases National Institute "Dr. Carlos G. Malbrán" for confirmation, serotyping, and antimicrobial susceptibility. Serotyping was performed by Quellung reaction and susceptibility testing by CLSI agar dilution method. MIC were interpreted according CLSI guidelines (22).

A nasopharyngeal aspirate was performed in case a respiratory viral infection was epidemiologically and/or clinically suspected.

\section{Data analysis}

Epi-Info program (Centers for Disease Control and Prevention, Atlanta, Georgia, United States) and Epidat 3.1 (Dirección Xeral de Saúde Pública, Xunta de Galicia, Spain) were used to perform data analysis. To evaluate vaccination impact, PBP annual incidence pre- and post-PCV13 introduction to NIP, was calculated by incidence rate ratio of the two periods $(95 \% \mathrm{CI})$ and decrease in the incidence rate $(P<0.05)$.

For post-vaccination period case description, median and interquartile range or mean and standard deviation (SD) for continuous variables and proportions for categorical data were calculated with $95 \% \mathrm{CI}$. For continuous data, analysis of T-test or Wilcoxon rank sum test, and chi-square test for proportions were used. Multivariable analyses were performed, using logistic regression to evaluate variables associated to present PBP and to those requiring hospitalization. OR with 95\%CI measured association. Alpha error of $5 \%$ was accepted. Calibration and discrimination of the model were evaluated by Hosmer-Lemenshow test and area under the curve.

\section{Ethics}

The study was approved by the Teaching and Research Committee of Masvernat Hospital. Because this was an epidemiological surveillance study without intervention on patients, informed consent was not required. All information provided by the participants and obtained in the laboratory was stored in a database with restricted access. Personal data was registered by a code (alphanumeric, two letters, three numbers) for each participant. Only researchers had access to the link between the code and the name and surname.

\section{RESULTS}

During November 2002 - October 2005 , the pre-PCV13 introduction period, there were 768 cases of CAP among children less than 5 years of age included in the study; of these, 459 were classified as PBP $(59.8 \%)$. During the period 1 April 2014 - 30 March 2016, post-introduction period, there were 330 cases of CAP among this age group, of which 92 (27.9\%; 95\%CI: 23.2 - 33.1) were PBP. Regarding the other variables, the study populations evaluated in both periods were similar, with no significant differences in distribution by age, sex, or type of care. Median of people sleeping per room was similar as well: 3 persons/ room, ranging from $1-9$, for the first period; and 3 persons/room, ranging from $1-4$, for second period (Table 1 ).

TABLE 1. Population characteristics in a study of the impact of pneumococcal conjugated vaccine (PCV13) introduction to the National Immunization Program in Argentina, among children less than 5 years of age in Concordia, Argentina, by study period

\begin{tabular}{|c|c|c|c|c|c|}
\hline \multirow[t]{2}{*}{ Variable } & \multicolumn{2}{|c|}{$\begin{array}{l}\text { Pre-introduction of } \\
\text { PCV13 (2002 - 2005) }\end{array}$} & \multicolumn{2}{|c|}{$\begin{array}{l}\text { Post-introduction of } \\
\text { PCV13 (2014 - 2016) }\end{array}$} & \multirow[t]{2}{*}{$P^{a}$} \\
\hline & $n$ & $\%$ & $n$ & $\%$ & \\
\hline Community acquired pneumonia (CAP) & 768 & & 330 & & \\
\hline Consolidated CAP and pleural effusion (probably) & 434 & 56.5 & 92 & 27.9 & $<0.0001$ \\
\hline Pneumococcal pneumonia (confirmed) & 25 & 3.3 & 0 & 0 & $<0.0001$ \\
\hline \multicolumn{6}{|l|}{ Age (months) } \\
\hline $0-11$ & 288 & 37.5 & 136 & 41.21 & \multirow{3}{*}{-} \\
\hline $12-23$ & 199 & 25.9 & 91 & 27.6 & \\
\hline $24-59$ & 281 & 36.5 & 103 & 31.2 & \\
\hline \multicolumn{6}{|l|}{ Gender } \\
\hline Female & 364 & 47.4 & 153 & 46.3 & \multirow{2}{*}{-} \\
\hline Male & 404 & 52.6 & 177 & 53.6 & \\
\hline \multicolumn{6}{|l|}{ Socioeconomic status } \\
\hline 1 & & & 2 & 0.6 & \multirow{5}{*}{-} \\
\hline 2 & & & 14 & 4.2 & \\
\hline 3 & \multirow{3}{*}{\multicolumn{2}{|c|}{ - }} & 90 & 27.3 & \\
\hline 4 & & & 203 & 61.5 & \\
\hline 5 & & & 21 & 6.3 & \\
\hline Nutritional status, eutrophic & 619 & 82.0 & 281 & 85.1 & - \\
\hline Nursery school/pre-kindergarten & 51 & 6.8 & 39 & 11.8 & 0.004 \\
\hline Receiving antibiotics in previous 3 months & 191 & 25.0 & 46 & 13.9 & 0.0001 \\
\hline Hospitalization in previous 3 months & & & 55 & 16.7 & \\
\hline Underlying disease & 347 & 45.5 & 162 & 49.1 & - \\
\hline \multicolumn{6}{|l|}{ Outcome } \\
\hline Cured & 758 & 98.9 & 327 & 99.1 & \multirow{3}{*}{-} \\
\hline Derived & 3 & 0.3 & 2 & 0.6 & \\
\hline Deceased & 5 & 0.6 & 1 & 0.3 & \\
\hline \multicolumn{6}{|l|}{ Health care service } \\
\hline Inpatient & 488 & 63.5 & 211 & 63.9 & \multirow{2}{*}{-} \\
\hline Outpatient & 280 & 36.4 & 117 & 35.4 & \\
\hline
\end{tabular}

${ }^{a}$ Chi-squared test.

Source: Prepared by the authors from the study results. 


\section{PBP incidence and vaccination impact}

PBP incidence in the post-vaccination period was 296.9 / 100000 in children less than 5 years of age. When compared with the previous study (PBP incidence 847.5 / 100 000), in the pre-PCV13 introduction, children had a higher risk of developing PBP than in the post-vaccination period: 2.8 (95\%CI: $2-4)$. As shown in Table 2, the decrease in PBP incidence in the post-vaccination period was $64.9 \%$ $(P<0.0001)$. A significant reduction of PBP incidence rates was found across all age groups between the pre-and the post-PCV13 introduction period (Table 2).

Invasive pneumococcal disease incidence in the pre-PCV13 introduction period was 46.2 / $100000(13,14)$. In the post-vaccination period, blood cultures were performed in 195 of the 211 patients hospitalized with CAP $(92.4 \%)$, and pleural fluid culture, in 4 of 6 with pleural effusion. All cultures were negative for S. pneumoniae.

\section{Post-vaccination cases characteristics}

This study reported 330 patients with CAP clinical diagnosis, 92 of which were PBP (6 with pleural effusion). Median age was 15 months and 64\% were hospitalized. Patient characteristics are described in Table 1.

Etiological diagnosis. Bacterial CAP was confirmed in 5 cases: $S$. aureus: Methicillin-resistant 2, Methicillin-sensitive 1;
H. influenzae capsular type 1 1, S. pyogenes 1 . Two of these patients presented pleural effusion (S. aureus methicillin-resistant 1 , S. pyogenes 1). Viral isolation was positive in 67 of 206 admissions (32.5\%), 28 classified as PBP (Table 3).

Severity. Eleven patients were admitted to intensive care units: 5 patients with confirmed bacterial CAP, 3 with PBP, and 3 with non-bacterial pneumonia (confirming Respiratory Syncytial Virus [RSV] infection in two of them). The 11-month-old female with $H$. influenzae capsular type $\mathrm{f}$ isolation without pathological history died.

Vaccination coverage. PCV13 coverage with dose 1 was $97.3 \%$ (95\%CI: 96.0 99.4), decreasing to $84.8 \%$ (95\%CI: 79.1 -90.5) by the booster dose. Regarding the coverage according to final classification, children with the booster dose had a lower incidence of bacterial CAP, but this difference was not statistically significant. There were also no significant differences in the occurrence of PBP with the 1st and 2nd doses of PCV13.

\section{Multivariate analysis}

The multivariate analysis found no factors associated with presenting PBP or confirmed bacterial pneumonia. Variables associated with hospitalization were:

- $\quad$ Presenting PBP (OR = 3.3; 95\%CI: $1.7-6.5)$

- Being in the 0 - 11-month age group had a higher risk of hospitalization than both the 12 23 months and $>24$ months age groups $(\mathrm{OR}=3.6$; $95 \% \mathrm{CI}$ : $1.0-6.9$; and $\mathrm{OR}=6.6$; $95 \% \mathrm{CI}: 3.3-13.1$, respectively).

- Having a hospitalization in the previous 3 months $(\mathrm{OR}=3.8$; 95\%CI: 1.5 - 10.04).

- Not being enrolled in nursery school or pre-kindergarten $(\mathrm{OR}=5.9 ; 95 \% \mathrm{CI}: 2.4-14.4)$

TABLE 3. Number of viral isolations by final classification in a study of the impact of pneumococcal conjugated vaccine (PCV13) among children less than 5 years of age in Concordia, Argentina. Post-vaccine introduction period, 2014 - 2016

\begin{tabular}{lccc}
\hline Virus & $\begin{array}{c}\text { Non-bacterial pneumonia } \\
(n)\end{array}$ & $\begin{array}{c}\text { PBPa } \\
(n)\end{array}$ & $\begin{array}{c}\text { Total } \\
(n)\end{array}$ \\
\hline Respiratory syncytial virus & 26 & 17 & 43 \\
Parainfluenza virus type 3 & 4 & 5 & 9 \\
Not typified & 4 & 4 & 8 \\
Adenovirus & 3 & 0 & 3 \\
Influenza virus & 1 & 2 & 3 \\
Parainfluenza virus type 1 & 1 & 0 & 1 \\
Total & 39 & 28 & 67 \\
\hline
\end{tabular}

a Probably bacterial pneumonia (consolidated pneumonia + pneumonia with pleural effusion).

Source: Prepared by the authors, from these results.

TABLE 2. Consolidated pneumonia and pleural effusion incidence in a study of the impact of pneumococcal conjugated vaccine (PCV13) among children less than 5 years of age in Concordia, Argentina, by study period and age group

\begin{tabular}{|c|c|c|c|c|c|c|c|c|c|}
\hline \multirow{2}{*}{ Final classification } & \multicolumn{3}{|c|}{$\begin{array}{l}\text { Pre-introduction of PCV13 } \\
(2002-2005)\end{array}$} & \multicolumn{3}{|c|}{$\begin{array}{c}\text { Post-introduction of PCV13 } \\
(2014-2016)\end{array}$} & \multicolumn{3}{|c|}{ Impact of vaccination } \\
\hline & $N$ & Populationa & Incidence ${ }^{\mathrm{b}}$ & $n$ & Populationc & Incidence ${ }^{\mathrm{b}}$ & $\begin{array}{l}\text { Incidence rate } \\
\text { ratio }(95 \% \mathrm{Cl})\end{array}$ & Decrease \% & $P$ value \\
\hline Consolidated pneumonia & 387 & 18053 & 714.6 & 88 & 15493 & 283.9 & $2.5(1.8-3.6)$ & 60.2 & $<0.001$ \\
\hline Pneumonia with pleural effusion & 72 & 18053 & 132.9 & 6 & 15493 & 19.4 & $6.7(2.1-35.6)$ & 85.4 & 0.004 \\
\hline $\operatorname{PBPe}($ total) & 459 & 18053 & 847.5 & 92 & 15493 & 296.9 & $2.8(2.0-4.0)$ & 64.9 & $<0.001$ \\
\hline \multicolumn{10}{|l|}{ PBP (by age group) } \\
\hline $0-11$ months & 158 & 3607 & 1469.4 & 44 & 3215 & 684.3 & $2.1(1.3-3.7)$ & 53.4 & 0.002 \\
\hline 12 - 23 months & 111 & 3440 & 1075.6 & 20 & 3101 & 322.5 & $3.3(1.6-7.5)$ & 70.0 & 0.001 \\
\hline$>2$ years & 190 & 11006 & 572.4 & 28 & 9177 & 152.6 & $3.7(2.1-7.3)$ & 73.3 & $<0.001$ \\
\hline
\end{tabular}

a National census 2001.

${ }^{\mathrm{b}}$ Annual incidence rate $<5$ years of age /100 000 individuals annually.

c National census 2010.

${ }^{d}$ Chi-squared test.

e Probably bacterial pneumonia (consolidated pneumonia + pneumonia with pleural effusion).

Source: Prepared by the authors from the study results and a previous study. 
The model presented good calibration (Hosmer-Lemeshow test: 0.6) and discrimination (area under the curve: 0.8).

\section{DISCUSSION}

This study supports the preventive role that PCV introduction has played worldwide. The study population in both periods was similar; however, we found statistically significant differences in terms of concurrence to nursery/prekindergarten and antibiotics use in the previous 3 months. The incidence of PBP and pneumonia with pleural effusion significantly decreased across all age groups. There was no S. pneumoniae isolation with the conventional laboratory media used.

The multivariate analysis showed that requiring hospitalization was associated with having PBP, being less than 12 months of age, having had previous hospitalizations, and not attending a nursery school or pre-kindergarten program.

In the United States, Moore and colleagues (23) reported PCV13 effectiveness in preventing invasive pneumococcal infections. Likewise, Farnjam and colleagues (24) described that following the introduction of PCV 13, incidence of invasive pneumococcal disease among children less than 5 years of age in New York City decreased dramatically, by $69.6 \%$ (95\% CI: $79.5 \%-55.5 \%$ ).

Several LAC countries have developed population-based studies using the WHO methodology for chest X-ray interpretation following introduction of PCV to their NIP. Hortal and colleagues (25) reported that in two municipalities of Uruguay (Salto and Paysandú), there was a significant reduction of consolidated CAP (44.9\%) among those less than 2 years of age compared to a previous period. PCV13 was implemented since 2010 with high coverage: $92 \%$. One year after vaccine introduction, Pírez and colleagues (26) found a significant reduction in hospitalization rates at the Pereyra Russell Hospital of Montevideo (Uruguay) due to CAP and invasive pneumococcal infections $(56 \%$ and $48.2 \%$, respectively). In the same study, meningitis incidence reduction in children less than 2 years of age was 59\% (26). Three cities in Brazil with high PCV10 coverage also reported a significant reduction in pneumonia incidence: Belo Horizonte $(28.7 \%)$, Recife $(27.4 \%)$, and Curitiba (23.3\%), but not São Paulo and Porto Alegre where coverage was lower (27). In Argentina, Gentile and colleagues (28) developed a population-based study in Pilar (Buenos Aires Province) during the first 2 years of postPCV13 introduction to the NIP. They reported a significant CAP decrease in 2013: in those less than 12 months of age $(44.6 \%)$ and $12-23$ months of age $(57.9 \%)$ but did not describe a decrease for older children (25 - 59 months of age). They concluded that vaccination had an impact among those less than 2 years of age, but not in older children due to the lower coverage in this age group. S. pneumoniae was isolated in four cases, with a significant decrease from a previous study. These data support the need to increase coverage to achieve impact in the prevention of invasive pneumococcal diseases (IPD) at all ages. Another study from Argentina (29) evaluated hospitalization burden for IPD and/or CAP in children younger than 5 years in the pre-vaccine $(2009$ - 2011) versus postvaccine $(2012-2013)$ periods. This multicentric study revealed significant decreases: $50 \% \quad(P=0.003)$ and $51 \%$ $(P<0.0001)$, respectively.

The present study, developed in Concordia with similar methodological characteristics to the study carried out in 2002 - 2005 (14), confirmed a high effectiveness of PCV13 to reduce CAP and pleural effusion incidence, even without pneumococcus isolation.

Notably, the number of vaccine doses was not related to PBP incidence, nor were any of the studied variables. PBP incidence in children with completed vaccine schedules did not have statistically significant differences compare to those who had not received all three doses $(2+1)$. These results might be explained by the fact that the study was performed in a population with high PCV13 coverage, with an important herd effect protecting unvaccinated contacts, including those presenting risk factors for PBP. Thus, massive vaccination with PCV13 would decrease the risk of PBP, independent of vaccination status or individual risk factor. These results emphasize the importance of maintaining high PCV vaccination coverage to protect an entire population.

Another factor to take into account is the important proportion of PBPs that had viral isolation, mainly RSV, an association also described in another study (30). It is accepted that "consolidating CAP definition" following the WHO guidelines, may present difficulties in interpreting chest X-ray infiltrates in some cases. In addition, respiratory viruses, including RSV, can generate consolidation images, as reported by Ruuskanen and colleagues (29). These authors concluded that viral etiology could not be ruled out because of the possibility that viruses can cause localized alveolar infiltrate. The virus-bacteria co-infection was documented in $18 \%$ of 220 children from 3 months - 16 years of age, predominantly S. pneumoniae $(8 \%)$, followed by M. pneumoniae (6\%); alveolar infiltrates (consolidation) were reported in $10 \%$ of the cases (31). Galván and colleagues documented these co-infections as a frequent condition (32); S. pneumoniae was isolated in several cases, increasing the severity of infection resulting in a prolonged hospital stay.

A systematic review conducted by PAHO in five LAC post-introduction of PCV to their NIP, reported effectiveness of $8.8 \%-37.8 \%$ for hospitalizations due to X-ray confirmed pneumonia; $7.4 \%-20.6 \%$ for clinical pneumonia; and $56 \%-83.3 \%$ for pneumococcal pneumonia (33). A study conducted in Israel (34) showed a moderate decline in hospital CAP visits for children less than 5 years of age after PCV7 introduction; in contrast, after PCV13 introduction, a substantial reduction in all visits was evident among those less than 12 months (44\%) and $24-59$ months (46\%).

Limitations. The study presented some limitations. Data from pre-introduction of PCV13 were not published; instead, the original database was used for that period, so the incidence data can be considered reliable. Including only patients from the public health system may also be a limitation. Nevertheless, it is estimated that more than $95 \%$ of the population is served by the public system.

Some sociodemographic variations were recorded between the two periods. According to information from the national censuses and from the provincial statistics department, the population of the study area increased by $30 \%$. Although poverty decreased, there were no general, significant changes. The health system and mortality rates for children less than 5 years of age were similar in both periods.

\section{Conclusions}

This study showed that universal PCV13 vaccination at 2 and 4 months, 
with a booster dose at 12 months, is effective in prevention of PBP cases in children less than 5 years of age, compared to the pre-PCV13 introduction period. The decrease in PBP incidence was significant for all ages, independent of vaccination status. There were no variables associated to presenting with PBP, probably because of the high population coverage with a vaccine that has an important herd effect. Children with a prior hospitalization (within 3 months), those less than 12 months of age, and those with PBP were associated with requiring hospitalization.
It is important to achieve high PCV13 vaccination coverage to decrease vaccine preventable diseases, such as pneumonia, not only in vaccinated groups, but also among all ages, particularly in Argentina and other LAC countries with high PBP rates. We also would like to highlight the importance of measuring the impact of this type of public health strategy in order to produce local evidence and strengthen decision-making.

Acknowledgements. The authors wish to thank the health team that collaborated with us in this study,

\section{REFERENCES}

1. Rudan I, Tomaskovic I, Boschi Pinto C Campbell H; WHO Child Health Epidemiology Reference Group. Global estimate of the incidence of clinical pneumonia among children under 5 years of age. Bull World Health Organ. 2004;82:89.

2. Hayes BL, George CM. Community-acquired pneumonia in children. Am Fam Physician. 2012;86(7):661-7.

3. Morris S, Black R,Tomaskovic L. Predicting the distribution of under 5 deaths by cause in countries without adequate vital registration systems. Int J Epidemiol. 2003;32:1041-51.

4. Poster S, Read J. Pediatric acquired pneumonia. S D Med. 2017;70(12):557-61.

5. Nair H, Simões EA, Rudan I, Gessner BD, Azziz-Baumgartner E, Zhang J, et al. Global and regional burden of hospital admissions for severe acute lower respiratory infections in young children in 2010: a systematic analysis. Lancet. 2013;381(9875): 1380-90.

6. Organización Panamericana de la Salud. Infecciones respiratorias agudas en las Américas. Bol Epidemiol OPS. 1995;16(4): $1-5$.

7. Constenla D, Gomez E, Pio de la $\mathrm{Hoz}$ FP, O'Loughlin R, Sinha A, Valencia JE, et al. The burden of Pneumococcal disease and cost-effectiveness of a Pneumococcal vaccine in Latin America and the Caribbean. Sabin Vaccine Institute. 2007;1:129. Available from: www.ispch. $\mathrm{cl} /$ sites/default/files/document1.pdf Accessed on 2 July 2018.

8. World Health Organization, Pneumonia Vaccine Trial Investigators' Group. Standardization of interpretation of chest radiographs for the diagnosis of pneumonia in children. Geneva: WHO; 2001.

9. Ferrero F, Nascimento-Carvalho CM, Cardoso MR, Camargos P, March MF, Berezin E, et al. Radiographic findings among children hospitalized with severe community-acquired Pneumonia. Pediatr Pulmonol. 2010;45(10):1009-13.

10. Lagos R, Muñoz A, Valenzuela MT, Heitmann I, et al. Population based surveillance for hospitalized and ambulatory pediatric invasive pneumococcal disease in Santiago, Chile. Pediatr Infect Dis J. 2002;21:1115-23.

11. Andrade AL, Oliveira R, Rodgers GL. Population-based surveillance for invasive pneumococcal disease and pneumonia in infants and young children in Goiania, Brazil. Vaccine. 2012;30(10):1901-9.

12. Hortal M, Estevan M, Iraola I,Mucio B. A population-based assessment of the disease burden of consolidated pneumonia in hospitalized children under five years of age. Int J Infect Dis. 2007;11:273-7.

13. Gentile A, Ruvinsky R, Bakir J, Gentile F, Kupervaser M, Quiriconi M, et al. Surveillance of probably bacterial Pneumonia in children less than 5 years old in two geographical areas in Argentina. Proceedings of the 45th Interscience Conference on Antimicrobial Agents and Chemotherapy. Washington DC: ICAAC; 2005.

14. Ruvinsky RO, Gentile A, Gentile LF, Gil C, Kupervaser J, Quiriconi $M$ et al. Surveillance of probable bacterial pneumonia in children less than 5 years old in two geographical areas in Argentina. Proceedings of the $15^{\text {th }}$ European Congress of Clinical Microbiology and Infectious Diseases. Copenhagen: European Society of Clinical Microbiology and Infectious Diseases; 2007.

15. Tregnaghi M, Ceballos A, Ruttiman R, Ussher J, Tregnaghi P, Peeters $\mathrm{P}$, et al. Active epidemiological surveillance of pneumonia and invasive pneumococcal disease in ambulatory and hospitalized infants in Córdoba, Argentina. Pediatr Infect Dis J. 2006;25:370-2.

16. Black $S$, Shinefield H, Fireman B, Lewis E, Ray P, Hansen JR et al. Efficacy, safety and immunigenicity of heptavalent pneumococcal conjugate vaccine in children. Pedi-

17. Deceuninck G, De Wals P, Boulianne N, Serres G. Effectiveness of pneumococcal conjugate vaccine using a $2+1$ infant schedule in Quebec, Canada. Pediatr Infect Dis J. 2010;29:546-9.

18. Loo JD, Conklin L, Fleming-Dutra KE, Deloria Knoll M, Park DE, Kirk J, et al. Systematic review of the effect of atr Infect Dis J. 2000;19:187-95. and the whole community of Concordia, Argentina.

Funding. The study was funded by the Ministry of Health of Argentina. The funders had no role in the study design, data collection or analysis, decision to publish, or preparation of the manuscript.

Conflict of interests. None declared.

Disclaimer. Authors hold sole responsibility for the views expressed in the manuscript, which may not necessarily reflect the opinion or policy of the RPSP/ PAJPH and/or PAHO. pneumococcal conjugate vaccine dosing schedules on prevention of pneumonia. Pediatr Infect Dis J. 2014;33(1):S140-51.

19. Ministerio de Salud de la Nación. Introducción de la vacuna conjugada anti neumocócica al Calendario Nacional de Inmunizaciones de la República Argentina. Lineamientos técnicos y manual del vacunador. Buenos Aires: MSN; 2011. Available from: www.msal.gov.ar/neumococo/descargas(lineamientos-neumococo-25-11-2011-pdf) Accessed 1 July 2015.

20. Censo Nacional de Población, Hogares y Viviendas 2010. Instituto Nacional de Estadísticas y Censos. República Argentina. Available from: https:/ /www.indec.gov.ar/ nivel4_default.asp?id_tema_1=2\&id_tema 2=41\&id_tema_3=135 Accessed 2 July 2018.

21. Méndez Castellano H. Sociedad y estratificación: método de Graffar-Mendez Castellano. Caracas: FUNDACREDESA; 1994.

22. Clinical and Laboratory Standards Institute. Performance standards for antimicrobial susceptibility testing; 19 th informational supplement (M100-S19). Wayne, Pennsylvania: Clinical and Laboratory Standards Institute; 2009.

23. Moore MR, Link-Gelles R, Schaffner W, Lynfield R, Holtzman C, Harrrison LH, et al. Effectiveness of 13-valent pneumococcal conjugate vaccine for prevention of invasive pneumococcal disease in children in the USA: a matched case-control study. Lancet Resp Dis.2016;4(5):399-406.

24. Farnham AC, Zimmerman CM, Papadouka V, Konty KJ, Zucker JR, Nattanmai GV, et al. Invasive pneumococcal disease following the introduction of $13-\mathrm{V}$ conjugate vaccine in children in New York City from 2007 to 2012. JAMA Pediatr. 2015;169(7):646-52.

25. Hortal M, Estevan M, Laurani H, Iraola I, Meny M; Paysandú/Salto Study Group. Hospitalized children with pneumonia in Uruguay: pre and post introduction of 7 and 13-valent pneumococcal conjugated vaccines into the National Immunization Program. Vaccine. 2012;30(33):4934-8.

26. Pírez MC, Algorta G, Cedrés A, Sobrero H, Varela A, Giachetto $G$, et al. Impact of 
universal pneumococcal vaccination on hospitalizations for pneumonia and meningitis in children in Montevideo, Uruguay. Pediatr Infect Dis J. 2011;30(8):669-74.

27. Afonso ET, Minamisava R, Bierrenbach $\mathrm{AL}$, Escalante JJ, Alencar AP, Domingues $\mathrm{CM}$, et al. Effect of 10-valent pneumococcal vaccine on pneumonia among children, Brazil. Emerg Infect Dis. 2013;19(4): 589-97.

28. A Gentile, J Bakir, L Bialorusb, Caruso L, Mirra D, Santander C, et al. Impacto de la vacuna neumocócicaconjugada 13-valente en la incidencia de neumonía consolidante en menores de 5 años en el partido de Pilar, Buenos Aires: estudio de base poblacional. Arch Argent Pediatr. 2015; 113(6):502-9.

29. López EL, Glatstein E, Ezcurra GC, Iacono M, Teplitz E, Garnero AV, et al. Rapid decrease in rates of hospitalization resulting from invasive Pneumococcal disease and CAP in children aged $<60$ months after $13-V$ pneumococcal conjugate vaccine introduction in Argentina. J Pediatr Infect Dis Soc. 2018;7(1):30-5.

30. Ruuskanen O, Lahti E, Jenningere C, Murdoch DR. Viral pneumonia. Lancet. 2011;377:1264-75.

31. Lehtiner P, Jartti T, Virkki R,Vuorinen T, Leinonen M, Peltola V, et al. Bacterial coinfection in children with viral wheezing. Eur J ClinMicrobiol Infect Dis.2006;25(7): 463-9bf.

32. Galvan JM, Rajas O, Aspa J. Review of non-bacterial infection in respiratory medicine: viral pneumonia. Arch Broncho Neumonol. 2015;51(11):590-7.

33. Oliveira LH, Camacho LA, Coutinho ES, Martinez-Silveira MS, Carvalho AF,
Ruiz-Matus C, et al. Impact and effectiveness of 10 and 13-valent pneumococcal conjugate vaccines on hospitalization and mortality in children aged less than 5 years in Latin American countries: a systematic review. Plos One. 2016;11(12):e0166736. doi 10.1371/journal.pone.0166736.

34. Greenberg D, Givon-Lavi N, Ben-Shimol $\mathrm{S}$, Ziv JB, Dagan R. Impact of PCV7/ PCV13 introduction on alveolar CAP in children $<5$ years. Vaccine. 2015;33(36): 4623-9.

Manuscript received on 4 November 2017. Accepted for publication on 29 May 2018
RESUMEN

Incidencia de la neumonía extrahospitalaria en menores de 5 años en Concordia (Argentina): repercusión de la vacunación

Palabras clave
Objetivo. Medir la efectividad de la vacuna antineumocócica conjugada (VNC13) contra la neumonía extrahospitalaria y las enfermedades neumocócicas invasoras, dos años después de que se incorporara la vacuna $(2+1)$ en el Programa Nacional de Vacunación de Argentina, y describir las variables asociadas con la neumonía bacteriana y la hospitalización.

Métodos. Se llevó a cabo un estudio prospectivo de vigilancia poblacional de la incidencia de la neumonía extrahospitalaria (pacientes ambulatorios y hospitalizados) en menores de 5 años en el departamento Concordia (Entre Ríos, Argentina) desde abril del 2014 hasta marzo del 2016. Se determinó el diagnóstico de probable neumonía bacteriana según el protocolo estandarizado de la OMS. Se comparó la incidencia durante el período posterior a la incorporación de la vacuna con los resultados de un estudio anterior en el que se usó una metodología similar para el período previo a la incorporación de la VNC13 entre el 2002 y el 2005.

Resultados. Durante el estudio, 330 pacientes presentaron un diagnóstico clínico de neumonía extrahospitalaria, de los cuales 92 presentaron probable neumonía bacteriana (6 con derrame pleural). No se aisló ninguna muestra del S. pneumoniae. No se encontraron factores asociados con la neumonía bacteriana probable en el análisis multivariante. La disminución de la neumonía bacteriana probable y el derrame pleural fue significativa en relación con el estudio anterior: $63 \%(P<0,0001)$ y 80,9\% $(\mathrm{P}<0,003)$, respectivamente. La absorción de la VNC13 fue de $97,3 \%$ para la primera dosis y de $84,8 \%$ para la dosis de refuerzo.

Conclusiones. La VNC13 fue efectiva para reducir la incidencia consolidada de derrame pleural y neumonía en menores de 5 años en Concordia (Argentina). La vacunación es una estrategia de salud pública muy efectiva para reducir las enfermedades prevenibles por vacunación, con repercusión en la carga de enfermedad y la hospitalización.

Neumonía neumocócica; Streptococcus pneumoniae; vacunas neumococicas; programas de inmunización, Argentina. 
RESUMO

Incidência de pneumonia adquirida na comunidade em crianças menores de 5 anos em Concordia, Argentina: impacto da vacinação

Palavras-chave
Objetivo. Avaliar a efetividade da vacina pneumocócica conjugada (PCV13) em prevenir pneumonia adquirida na comunidade (PAC) e doença pneumocócica invasiva (DPI) após 2 anos da incorporação da vacina $(2+1)$ ao Programa Nacional de Vacinação da Argentina e descrever as variáveis associadas à ocorrência de pneumonia bacteriana e internação hospitalar.

Métodos. Estudo prospectivo de base populacional de vigilância da incidência de PAC (atendimento ambulatorial e em internação hospitalar) em crianças menores de 5 anos de idade realizado no Departamento de Concordia, Entre Rios, na Argentina, de abril de 2014 a março de 2016. O diagnóstico de provável pneumonia bacteriana foi determinado segundo o protocolo padronizado da OMS. A incidência no período pós-introdução da vacina foi comparada aos resultados de um estudo anterior realizado com metodologia semelhante no período pré-introdução da PCV13 de 2002 a 2005.

Resultados. No período de estudo, foi feito o diagnóstico clínico de PAC em 330 pacientes, dos quais 92 foram casos de provável pneumonia bacteriana $(6 \mathrm{com}$ derrame pleural). A bactéria Streptococcus pneumoniae não foi isolada em nenhuma amostra. Não foi observado nenhum fator associado à provável pneumonia bacteriana na análise multivariada. Houve uma redução significativa da ocorrência de provável pneumonia bacteriana e derrame pleural em relação ao estudo anterior: $63 \%(\mathrm{P}<0,0001)$ e 80,9\% (P<0,003), respectivamente. A cobertura vacinal de PCV13 foi de $97,3 \%$ para a primeira dose e $84,8 \%$ para a dose de reforço.

Conclusões. A PCV13 foi efetiva em reduzir a incidência de pneumonia com consolidação e derrame pleural em crianças menores de 5 anos em Concordia, na Argentina. A vacinação é uma estratégia de saúde pública muito efetiva para reduzir doenças que podem ser evitadas com vacina, com impacto na morbidade e nas internações hospitalares.

Pneumonia pneumocócica; Streptococcus pneumoniae; vacinas pneumocócicas; programas de imunização, Argentina. 